\title{
Storage of cut Heliconia bihai (L.) Cv. Lobster Claw flowers at low temperatures
}

\author{
Andreza S. Costa ${ }^{1}$, Luis C. N ogueira ${ }^{2}$, Venézio F. dos Santos ${ }^{3}$, \\ Terezinha R. Camara ${ }^{4}$, Vivian Loges ${ }^{1} \&$ Lilia W illadino $^{4}$
}

\begin{abstract}
The postharvest conservation of cut Heliconia flowers is an important factor to the success of commercialization, especially with regard to exportation. In the present study, the maximal storage time of cut inflorescences of Heliconia bihai $\mathrm{cv}$. Lobster Claw at two different temperatures $\left(12\right.$ and $\left.19^{\circ} \mathrm{C}\right)$ was evaluated and compared to laboratory conditions $\left(25^{\circ} \mathrm{C}\right.$, control treatment). Changes in visual quality, fresh weight and bract color $\left(L^{*}, a^{*}\right.$ and $\left.b^{*}\right)$ were determined. The visual quality of the inflorescences and fresh weight decreased with time in all treatments. Symptoms of chilling injury were observed on the inflorescences stored at $12{ }^{\circ} \mathrm{C}$ for six and eight days. Bract color was not affected by temperature, storage time or the senescence process. The results indicate that a temperature of $12{ }^{\circ} \mathrm{C}$ is not recommended for a storage time longer than four days, whereas $19^{\circ} \mathrm{C}$ can be used for a storage time of up to eight days for cut inflorescences of $\mathrm{H}$. bihai $\mathrm{cv}$. Lobster Claw.
\end{abstract}

Key words: chilling injury, colorimetry, senescence, tropical flower, vase life

\section{Armazenamento de hastes florais de Heliconia bihai (L.) Cv. Lobster Claw em baixa temperatura}

\section{RESUMO}

A conservação pós-colheita de flores de corte de Heliconia é fator relevante para o sucesso da comercialização, principalmente para a exportação. $N$ este estudo, o período máximo de armazenamento de hastes florais de Heliconia bihai cv. Lobster Claw, foi avaliado em duas diferentes temperaturas (12 e $19{ }^{\circ} \mathrm{C}$ ) e comparado com as condições de laboratório $\left(25^{\circ} \mathrm{C}\right.$, tratamento controle). As variáveis avaliadas foram: qualidade visual, massa de matéria fresca e a coloração das inflorescências ( $L^{*}, a^{*}$ e $\left.b^{*}\right)$. A qualidade visual das inflorescências e a massa de matéria fresca de todos os tratamentos reduziram ao longo do tempo. Sintomas de injúria por frio foram observados nas inflorescências armazenadas a 12 ${ }^{\circ} \mathrm{C}$, durante seis e oito dias. A coloração das brácteas não foi afetada pela temperatura, período de armazenamento nem pelo processo de senescência. Os resultados indicam que a temperatura de $12{ }^{\circ} \mathrm{C}$ não é recomendada para armazenar hastes florais de Heliconia bihai cv. Lobster Claw por um período maior que quatro dias. A temperatura de $19{ }^{\circ} \mathrm{C}$ pode ser usada para armazenar hastes florais por um período de até oito dias.

Palavras-chave: injúria por frio, colorimetria, senescência, flor tropical, vida em vaso

\footnotetext{
${ }^{1}$ Laboratory of Floriculture, Department of Agronomy, U niversidade Federal Rural de Pernambuco (UFRPE), Av. Dom Manoel de Medeiros, s/n, CEP 52171-900, Recife, PE. Fone: (81) 3320-6250. E-mail: andreza.costa@gmail.com; vloges@yahoo.com

2 Embrapa Coastal Tablelands (CPATC), CEP 40025-040, Aracaju, SE. E-mail: Icnogueira@gmail.com

${ }^{3}$ Agricultural Research Institute of Pernambuco (IPA), CEP 50761-000, Recife, PE. E-mail: venezio@ipa.br

${ }^{4}$ Department of Biology/U FRPE. Fone: (81) 3320-6366. E-mail: tkrcamara@bol.com.br; lilia.willadino@bol.com.br
} 


\section{INTRODUCTION}

Many species of the genus Heliconia (Heliconiaceae family) are found in all tropical regions of the world due to their horticultural and commercial popularity. Cut Heliconia flowers are well known for their beauty, different shapes and impressive colors (Berry \& Kress, 1991). Heliconia bihai has an erect, firm inflorescence, which is an important trait for cut flowers, as it facilitates handling and packaging, offers strength during transportation and allows a longer vase life (Castro et al., 2006). Some cultivars have a continuous flowering cycle throughout the year. Thus, varieties of $H$. bihai are the most commercialized of all species of Heliconia in the Brazilian market.

Producers, distributors and retailers need to keep flowers and foliages at low temperatures in order to ensure the adequate maintenance of quality (Silva, 2003). According to Reid (1991), reducing the temperature reduces the rate of metabolism, water loss and attack from microorganisms and retards the process of senescence and tissue deterioration in harvested ornamental plants. Lowering the temperature during postharvest storage is normally beneficial. However, temperatures below the critical point of a given species can have harmful effects (Reid, 1991). Inadequate temperature during marketing is a major factor for the loss of quality and reduction in vase life of cut flowers (Reid, 2001), resulting in a larger number of discarded flowers.

Exposure to inadequately low temperature can cause a physiological disorder known as chilling injury (Skog, 1998). The severity of symptoms of chilling injury on a plant or its organs depends on temperature, exposition time and sensitivity of the genotype (Kays, 1991). Many flowers of a tropical origin may suffer chilling injury at temperatures below $10^{\circ} \mathrm{C}$ (Reid, 1991). The vase life of Strelitzia reginae, which is a subtropical flower, is reported to be continuously reduced when stored at $10^{\circ} \mathrm{C}$ and the storage period is extended from seven to 28 days (Finger et al., 2003). For species of Heliconia in general, transportation and storage at temperatures above $10{ }^{\circ} \mathrm{C}$ is recommended (Jaroenkit \& Paull, 2003); however, there is no specific recommendation for varieties of $H$. bihai.

The development of postharvest technology should include the evaluation of different storage alternatives used to achieve a gain of days in the flower conservation period (Sonego \& Brackmann, 1995). The aim of the present study was to evaluate the effect of the cold storage of flowering stems of Heliconia bihai cv. Lobster Claw, determining physical and chemical parameters at two different temperatures $\left(12\right.$ and $\left.19^{\circ} \mathrm{C}\right)$ in four storage periods (two, four, six and eight days).

\section{Material AND METHODS}

\section{Plant material and treatments}

Flowering stems of $H$. bihai cv. Lobster Claw were harvested from a commercial field with microsprinkling irrigation (latitude $7^{\circ} 56^{\prime} \mathrm{S}$, longitude $34^{\circ} 55^{\prime} \mathrm{W}$, altitude $14 \mathrm{~m}$ ) located in the municipality of Paulista, state of Pernambuco, Brazil, which is part of Atlantic Rainforest Zone.

The experiment was carried out at the Floriculture Laboratory of the Universidade Federal Rural de Pernambuco (Brazil) from
April to May 2008. Flowering stems with one to four open bracts were harvested in the early morning, as the farmers normally do when supplying the domestic and export markets. The inflorescences were cleaned (removing the flowers from inside the bracts), washed and cut to a standardized stem length of $80 \mathrm{~cm}$. The flowering stems were kept in distilled water for hydration until the following day, when they were submitted to different temperatures and storage periods.

The flowering stems were submitted to two treatments in cold chambers for two, four, six and eight days. Temperature and relative humidity were respectively $12{ }^{\circ} \mathrm{C}$ and $98 \%$ in Chamber 1 , and $19{ }^{\circ} \mathrm{C}$ and $99 \%$ in Chamber 2. As a control treatment, flowering stems were kept under laboratory conditions (LC) at a temperature of $25^{\circ} \mathrm{C}$, relative humidity of $77 \%$, and illuminance of $133.91 \mathrm{x}$. All variables were monitored using data loggers and sensors under each condition (HOBO, Onset Computers Co., Massachusetts, USA).

The flowering stems stored at low temperature in the cold chambers were packed in cardboard boxes $(0.85 \times 0.20 \times 0.50 \mathrm{~m})$ used for the commercialization of these products. Each inflorescence was wrapped in newspaper and separated in layers with shredded paper to avoid mechanical injury, as the farmers do for export. Each cardboard box was previously lined with bubble plastic in order to wrap all the flowering stems. After the storage treatments (four different periods), the flowering stems were kept in distilled water under LC for subsequent evaluations. Flowering stems in the control treatment were kept in distilled water under LC and evaluated when each treatment was removed from the cold chambers.

\section{Postharvest visual quality}

The visual quality of the flowering stems of $H$. bihai cv. Lobster Claw was evaluated with a rating scale during vase life every two days. A four-category rating scale was designed for assessing senescence symptoms (SS) or chilling injury symptoms (IS): Grade 4 -inflorescence with natural brightness and no brownish wilting areas at the apex of the bracts (SS) or spotless bracts (IS); Grade 3 - inflorescence with natural brightness and brownish wilting areas less than $1.0 \mathrm{~cm}$ from the apex of the bracts (SS) or bracts slightly spotted (IS); Grade 2 - bracts with brownish wilting areas between 1.0 and $5.0 \mathrm{~cm}$ from the apex of the bracts (SS) or bracts with dark spots (IS); and Grade 1 - inflorescence no turgescence, no natural brightness and with brownish wilting areas more than $5.0 \mathrm{~cm}$ from the apex of the bracts (SS) or bracts with intense dark spots (IS).

All the flowering stems of each treatment were discarded when more than $50 \%$ had reached Grade 1 . In the present study, vase life (VL) was defined as the number of days of durability of flowering stems after being removed from the cold chamber. The flowering stems were kept in distilled water under LC until the day of discard. Total postharvest longevity (TPL) was calculated by summing the days of refrigerated storage and days of vase life.

\section{Percentage fresh weight}

The fresh weight of all individual flowering stems was evaluated using a digital scale. Initial fresh weight was 
considered $100 \%$ for the determination of subsequent relative values.

\section{Determination of bract color}

Changes in bract color were determined with the aid of a colorimeter (CR-10 Konica Minolta) using the CIELab system. Color measurement was performed by placing the sensor on the bract surface at the base of the last bract of the inflorescence (closed bract, known as the "pointer"). Based on the method proposed by McGuire (1992), the following data were collected: $\mathrm{L}^{*}$ - lightness, representing the interval between black and white; $\mathrm{a}^{*}$ - interval between green (-) and red (+) colors; and $\mathrm{b}^{*}-$ interval between blue $(-)$ and yellow $(+)$ colors.

\section{Experimental design and statistical analysis}

A completely randomized experimental design was used, with nine treatments and three replications. The nine treatments were obtained from a $2 \times 4$ factor arrangement combining two different temperatures $\left(12\right.$ and $19^{\circ} \mathrm{C}$ ) and four storage periods (two, four, six and eight days) plus the control treatment. The analyses of fresh weight and bract color were based on three replicates with three flowering stems per plot.

The data were submitted to analysis of variance (ANOVA) and mean values were compared with Tukey's test $(\mathrm{p}<0.05)$ using the SAEG statistical program (SAEG, 1983).

\section{RESULTS AND DISCUSSION}

The visual quality of inflorescences of $H$. bihai cv. Lobster Claw underwent a reduction throughout the vase life (Table 1) either due to chilling injury (Figures 1 and 2) or senescence (Figure 3). Only the inflorescences stored at $12{ }^{\circ} \mathrm{C}$ for six days (Figure 1) and eight days (Figure 2) exhibited symptoms of chilling injury. In general, the inflorescences underwent a reduction in visual quality due to chilling injury starting on the second day after removal from the cold chambers at both temperatures. Eight days of cold storage caused more accentuated symptoms in comparison to six days of cold storage. Inflorescences that were kept under LC (control treatment) exhibited the loss of visual quality due to senescence starting on the fourth day (Figure 3).
The vase life of flowering stems kept under $\mathrm{LC}\left(25^{\circ} \mathrm{C}\right)$ was longer than the vase life of flowering stems kept in the cold chambers $\left(12\right.$ and $\left.19{ }^{\circ} \mathrm{C}\right)$, regardless of the storage period $(2,4$, 6 and 8 days) (Table 2). The flowering stems stored for two and four days at $12{ }^{\circ} \mathrm{C}$ and four days at $19^{\circ} \mathrm{C}$ had a vase life longer than seven days. This aspect is especially important to the commercialization of cut flowers, considering a normal interval of seven days between shopping events by regular consumers.

Regarding vase life, the best result was obtained with the control treatment (11.78 days). This indicates the possibility of transportation from the point of production to stores without the need for refrigeration in cold chambers for distances of about $100 \mathrm{~km}$, which is the typical situation for agricultural zones around major cities in Brazil. However, sales points (store environments) should be air conditioned to $25^{\circ} \mathrm{C}$, on average, to optimize the maintenance of the quality of the inflorescences during vase life, which is of major interest to consumers.

The best results regarding total postharvest longevity (TPL) were achieved with inflorescences stored at $12{ }^{\circ} \mathrm{C}$ for four days (TPL $=12.67$ days) and $19^{\circ} \mathrm{C}$ for eight days (TPL $=14.22$ days), demonstrating a short extension in comparison to the control treatment (Table 2). The inflorescences stored at $12{ }^{\circ} \mathrm{C}$ for two days and $19^{\circ} \mathrm{C}$ for four and six days had a TPL equivalent to the control treatment (above 11 days). This information allows inferences regarding the possibility of cost reductions when no refrigeration is needed between the production and commercialization points. Although airplanes for long distance transportation seems to be the most logical choice, according to Gorsel (1994), temperature control at airport facilities and on aircraft is often poor, which implies a potential loss in quality and longevity of the cut flowers. Transportation can be carried out by boat or truck, but careful temperature control is required along all parts of the way between the sender and receiver.

Flowers from subtropical environments require lower temperatures for quality conservation. According to Bellé et al. (2004), storage at a temperature of $2{ }^{\circ} \mathrm{C}$ retards the onset of symptoms of senescence in Dendranthema grandiflora. Bosma $\&$ Dole (2002) report a reduction in the life of Campanula medium flowers stored at $2{ }^{\circ} \mathrm{C}$ when the storage time increased from one to three weeks. Flowering stems of Strelitzia reginae stored at $10{ }^{\circ} \mathrm{C}$ for seven days have a longer vase life than when stored for 14, 21 and 28 days (Finger et al., 2003). This

Table 1. Visual quality of inflorescences of $\mathrm{H}$. bihai $\mathrm{Cv}$. Lobster Claw evaluated with rating scale during vase life at $25^{\circ} \mathrm{C}$ and $\mathrm{RH}$ of $77 \%$ under laboratory conditions (LC, control treatment) after storage in cold chambers at 12 and $19^{\circ} \mathrm{C}$ for 2 , 4,6 and 8 days

\begin{tabular}{|c|c|c|c|c|c|c|c|}
\hline \multicolumn{8}{|c|}{ Vase life (days) } \\
\hline Treatment & 0 & 2 & 4 & 6 & 8 & 10 & 12 \\
\hline LC (control) & $4.00 \mathrm{Aa}$ & $4.00 \mathrm{Aa}$ & $3.22 \mathrm{Ab}$ & $2.89 \mathrm{Ab}$ & $2.22 \mathrm{Ac}$ & $1.89 \mathrm{AC}$ & $1.22 \mathrm{~d}$ \\
\hline 2 days at $12^{\circ} \mathrm{C}$ & $3.89 \mathrm{Aa}$ & $3.11 \mathrm{Bb}$ & $2.67 \mathrm{ABbC}$ & $2.22 \mathrm{Bcd}$ & $1.89 \mathrm{ABde}$ & $1.33 \mathrm{Be}$ & \\
\hline 4 days at $12^{\circ} \mathrm{C}$ & $3.33 \mathrm{Aba}$ & $2.78 \mathrm{BCab}$ & $2.44 \mathrm{BCb}$ & $1.78 \mathrm{BCC}$ & $1.56 \mathrm{Bcd}$ & $1.11 \mathrm{Bd}$ & \\
\hline 6 days at $12^{\circ} \mathrm{C}$ & $3.44 \mathrm{Aba}$ & $2.33 \mathrm{CDb}$ & $1.44 \mathrm{Ec}$ & & & & \\
\hline 8 days at $12^{\circ} \mathrm{C}$ & $3.78 \mathrm{Aa}$ & $1.33 \mathrm{~Eb}$ & & & & & \\
\hline 2 days at $19^{\circ} \mathrm{C}$ & 3.67 Aba & $3.00 \mathrm{BCb}$ & $2.33 \mathrm{BCDC}$ & $1.44 \mathrm{Cd}$ & & & \\
\hline 4 days at $19^{\circ} \mathrm{C}$ & $3.00 \mathrm{Ba}$ & $2.56 \mathrm{BCDab}$ & $2.11 \mathrm{BCDEb}$ & $1.78 \mathrm{BCcd}$ & 1.33 Bd & & \\
\hline 6 days at $19^{\circ} \mathrm{C}$ & $3.44 \mathrm{Aba}$ & $2.67 \mathrm{BCb}$ & $1.78 \mathrm{CDEC}$ & $1.44 \mathrm{Cc}$ & & & \\
\hline 8 days at $19^{\circ} \mathrm{C}$ & $3.33 \mathrm{Aba}$ & 1.89 DEb & 1.67 Deb & $1.56 \mathrm{Cb}$ & $1.33 \mathrm{Bb}$ & & \\
\hline
\end{tabular}

Note: Means followed by same capital letters in columns and lowercase letters on lines do not differ significantly ( $p<0.05$; Tukey's test) 
A.

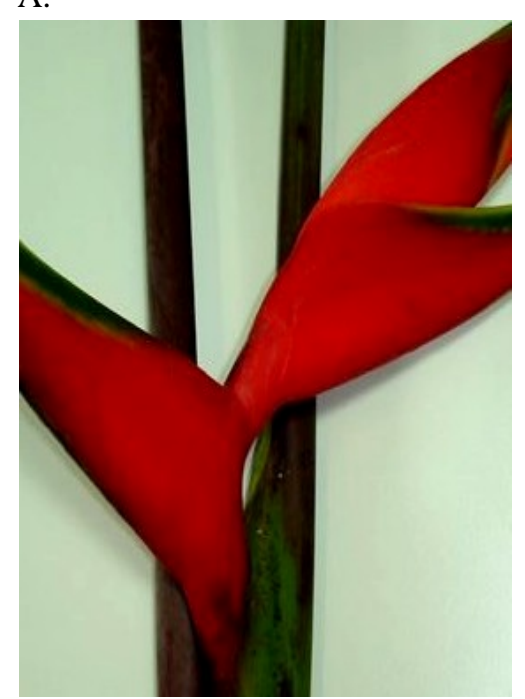

B.

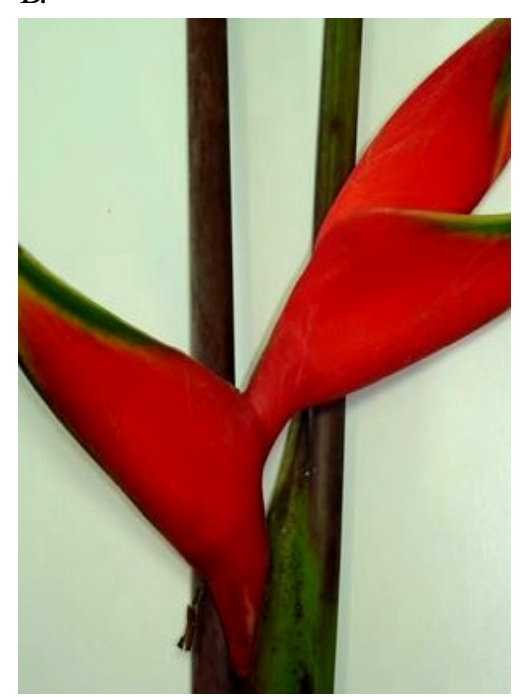

C.

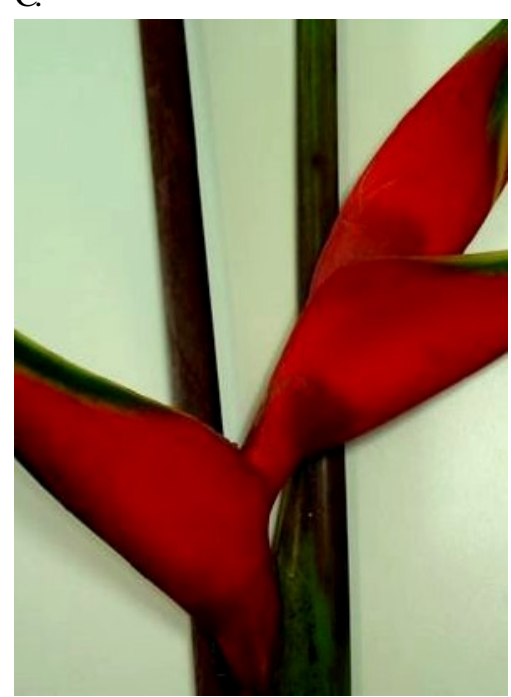

Figure 1. Symptoms of chilling injury on inflorescences of $\mathrm{H}$. bihai $\mathrm{cv}$. Lobster Claw stored in cold chamber at $12{ }^{\circ} \mathrm{C}$ for six days: A) Inflorescence prior to cold storage; B) same day after removal from cold chamber; and C) two days after removal from cold chamber

A.

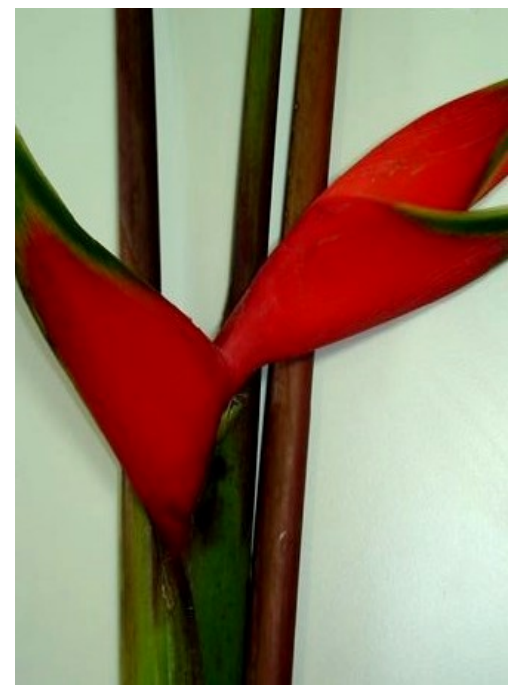

B.

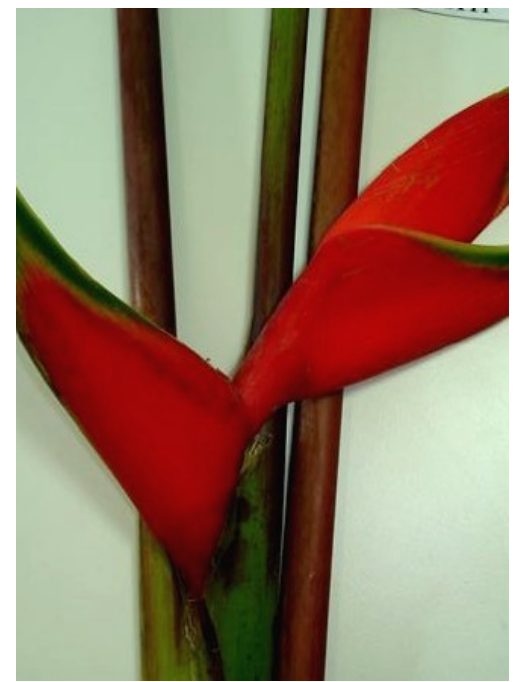

C.

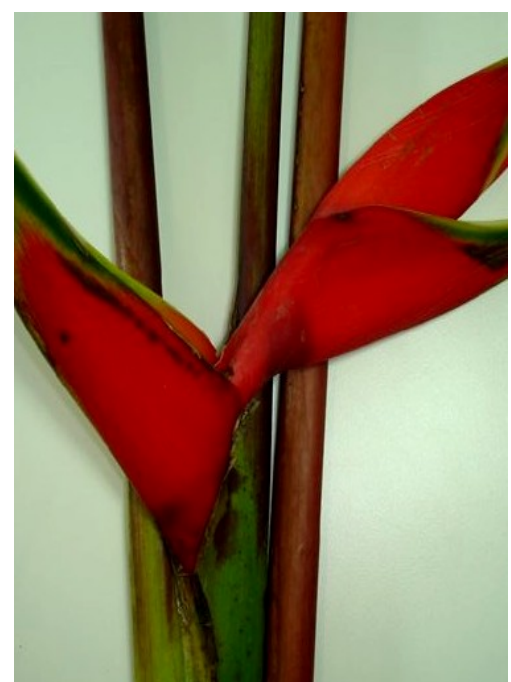

Figure 2. Symptoms of chilling injury on inflorescences of $\mathrm{H}$. bihai $\mathrm{Cv}$. Lobster $\mathrm{Claw}$ stored in cold chamber at $12{ }^{\circ} \mathrm{C}$ for eight days: A) Inflorescence prior to cold storage; B) same day after removal from cold chamber; and C) two days after removal from cold chamber

wide range of possibilities underscores the importance of defining storage time based on species and cultivar, which is reflected in the vase life of cut flowers.

Flowering stems stored at $12{ }^{\circ} \mathrm{C}$ for six and eight days had a shorter vase life than those stored for four days (Table 2) due to symptoms of chilling injury, which appeared soon after removal from the refrigerated conditions. Thus, the occurrence of chilling injury symptoms does not permit storage periods for longer than four days. The bracts with symptoms of chilling injury appeared slightly spotted after being removed from the refrigerated conditions (Table 1). The severity of chilling injury in a plant or its organs varies as a function of temperature, exposure time and the susceptibility of each species (Kays, 1991).

Flowering stems stored for eight days at $19{ }^{\circ} \mathrm{C}$ had a longer total postharvest longevity (14.22 days) than those in the control treatment (LC) (11.78 days) (Table 2), resulting in an increment of 2.44 days. This finding indicates the possibility of maintaining inflorescence quality during transportation over long distances. Except for the flowering stems stored for six days at $12{ }^{\circ} \mathrm{C}$ and for two days at $19^{\circ} \mathrm{C}$, no statistically significant differences in TPL values were detected among all other treatments, including the control (Table 2).

There was no difference in fresh weight (FW) values between flowering stems in the control treatment after harvest and flowering stems immediately after removal from cold chambers at 12 or $19^{\circ} \mathrm{C}$, regardless of the storage period $(2,4$, 6 and 8) (Table 3). This finding indicates that keeping the Heliconia flowering stems under these storage conditions does not lead to the loss of FW or visual quality, except when inflorescences are kept at $19{ }^{\circ} \mathrm{C}$ for four days (Tables 1 and 3). 
A.

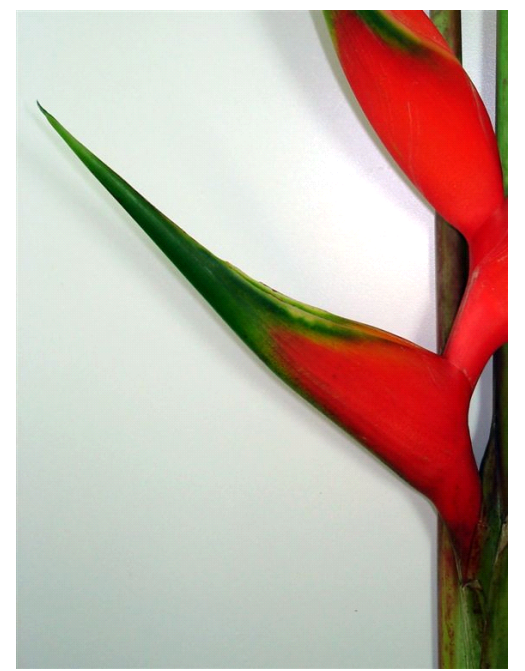

D.

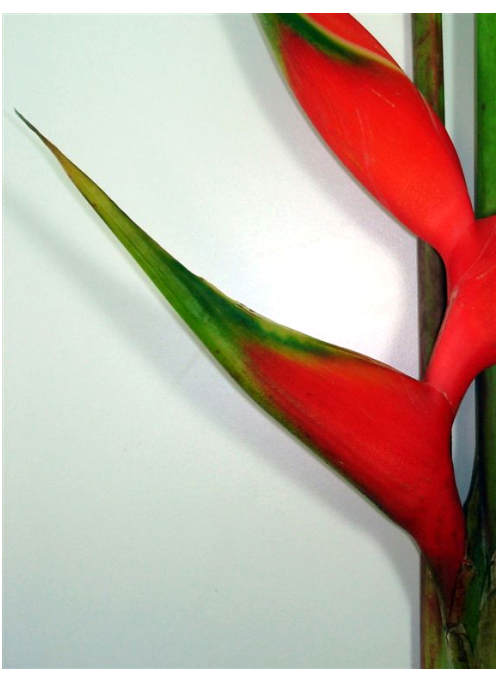

B.

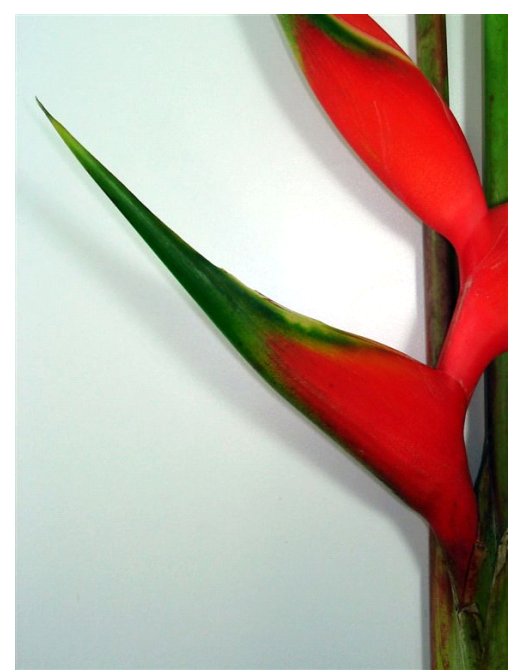

E

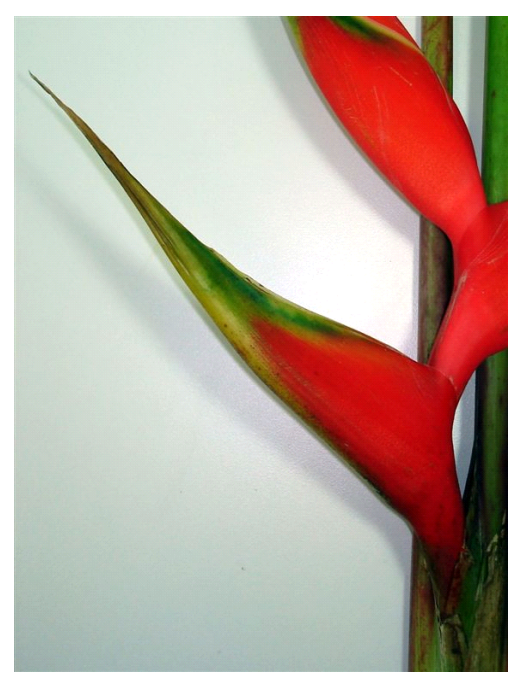

C.

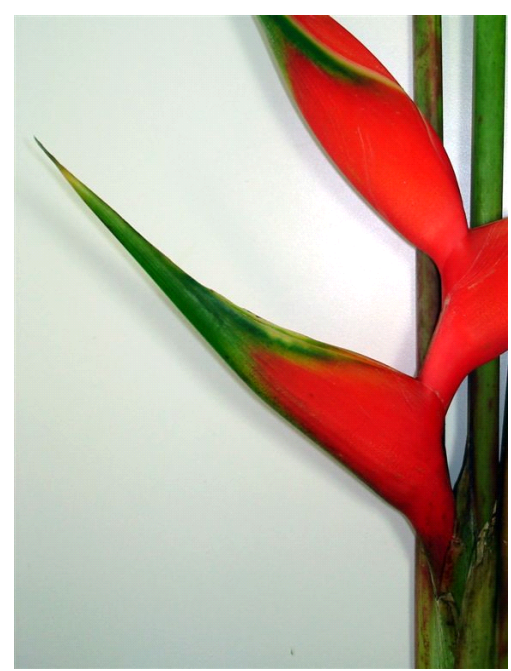

F.

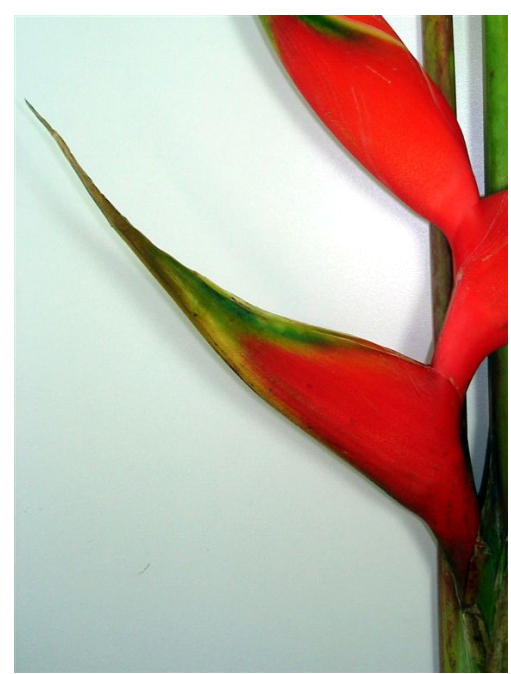

Figure 3. Symptoms of senescence on inflorescences of $\mathrm{H}$. bihai $\mathrm{cv}$. Lobster Claw kept at $25^{\circ} \mathrm{C}$ and $\mathrm{RH}$ of $77 \%$ (control treatment): A) Inflorescence after two days; B) after four days; C) after six days; D) after eight days; E) after ten days; and F) after twelve days under laboratory conditions

Table 2. Vase life and total postharvest longevity of flowering stems of $\mathrm{H}$. bihai $\mathrm{Cv}$. Lobster Claw kept at $25^{\circ} \mathrm{C}$ under laboratory conditions (LC, control treatment) and after storage in cold chambers at 12 and $19^{\circ} \mathrm{C}$ for $2,4,6$ and 8 days

\begin{tabular}{lcc}
\hline \multicolumn{1}{c}{ Treatment } & VL (days) & TPL (days) \\
LC (control) & $11.78 \mathrm{a}$ & $11.78 \mathrm{bc}$ \\
2 days at $12{ }^{\circ} \mathrm{C}$ & $9.56 \mathrm{~b}$ & $11.56 \mathrm{bcd}$ \\
4 days at $12^{\circ} \mathrm{C}$ & $8.67 \mathrm{bC}$ & $2.67 \mathrm{ab}$ \\
6 days at $12^{\circ} \mathrm{C}$ & $3.78 \mathrm{ef}$ & $9.78 \mathrm{~d}$ \\
8 days at $12^{\circ} \mathrm{C}$ & $2.00 \mathrm{f}$ & $10.00 \mathrm{~cd}$ \\
2 days at $19^{\circ} \mathrm{C}$ & $5.78 \mathrm{~d}$ & $7.78 \mathrm{e}$ \\
4 days at $19^{\circ} \mathrm{C}$ & $7.11 \mathrm{~cd}$ & $11.11 \mathrm{bcd}$ \\
6 days at $19^{\circ} \mathrm{C}$ & $5.56 \mathrm{de}$ & $11.56 \mathrm{bcd}$ \\
8 days at $19^{\circ} \mathrm{C}$ & $6.22 \mathrm{~d}$ & $14.22 \mathrm{a}$ \\
\hline
\end{tabular}

Note: Means followed by same lowercase letters in columns do not differ significantly $(p<0.05$; Tukey's test); VL - Vase life (days after cold storage); TPL - Total postharvest longevity (VL plus days of cold storage)

A previous study on Ctenanthe setosa (foliage) found that storage periods of four, five and six days $\left(25 \pm 1^{\circ} \mathrm{C}\right.$ and RH 65$70 \%$ ) increased the loss of fresh weight when compared to one and two days of storage (Geerdink et al., 2007). Joyce et al. (2000) report that inflorescences of Grevillea 'Sylvia' stored at $22{ }^{\circ} \mathrm{C}$ had lower values of fresh weight during vase life than inflorescences that had not been stored.

The flowering stems in all treatments underwent a gradual reduction in FW four days following removal from the refrigerated conditions (Table 3 ). This effect was probably due to the process of senescence promoted by physiological changes, such as water loss (Mayak, 1987). Flowering stems of Alpinia purpurata kept in distilled water are reported to undergo a reduction of FW over 16 days of vase life (Mattiuz et al., 2003). Flowering stems of Zingiber spectabilis are reported to undergo a gradual reduction in FW between harvest $(298.1 \mathrm{~g})$ and the time of discard $(241.7 \mathrm{~g})$ when kept in a controlled environment $\left(17 \pm 2{ }^{\circ} \mathrm{C}\right.$ and $\left.70 \% \mathrm{RH}\right)$ for 14 days (Santos et al., 2008). A high degree of water loss is reported for flowering stems of Curcuma alismatifolia kept in distilled water between two and four days (Chanasut, 2005).

The control treatment and the treatments stored at 12 and $19^{\circ} \mathrm{C}$ for two, four, six and eight days did not lead to an alteration 
Table 3. Fresh weight of flow ering stems of $\mathrm{H}$. bihai $\mathrm{Cv}$. Lobster Claw kept at $25^{\circ} \mathrm{C}$ under laboratory conditions (LC, control treatment) and after storage in cold chambers at 12 and $19^{\circ} \mathrm{C}$

\begin{tabular}{|c|c|c|c|c|c|c|c|}
\hline \multirow{3}{*}{ Treatment } & \multicolumn{7}{|c|}{ Fresh weight (\%) of flowering stems } \\
\hline & \multicolumn{7}{|c|}{ Vase life (days) } \\
\hline & 0 & 2 & 4 & 6 & 8 & 10 & 12 \\
\hline LC (control) & $100.00 \mathrm{Aa}$ & $97.79 \mathrm{Aa}$ & $96.78 \mathrm{Aab}$ & $93.55 \mathrm{Ab}$ & $89.97 \mathrm{Ac}$ & $86.75 \mathrm{Ac}$ & $83.07 \mathrm{~d}$ \\
\hline 2 days at $12^{\circ} \mathrm{C}$ & $98.37 \mathrm{Aa}$ & 96.28 ABab & $93.02 \mathrm{Bbc}$ & $89.97 \mathrm{BC}$ & $86.54 \mathrm{Bd}$ & $82.44 \mathrm{Be}$ & \\
\hline 4 days at $12^{\circ} \mathrm{C}$ & $97.36 \mathrm{Aa}$ & $94.72 \mathrm{ABCa}$ & $90.87 \mathrm{BCb}$ & $87.09 \mathrm{BCC}$ & $83.73 \mathrm{BCd}$ & $79.67 \mathrm{Ce}$ & \\
\hline 6 days at $12{ }^{\circ} \mathrm{C}$ & $97.69 \mathrm{Aa}$ & $94.32 \mathrm{ABCb}$ & $89.22 \mathrm{Cc}$ & & & & \\
\hline 8 days at $12{ }^{\circ} \mathrm{C}$ & $97.28 \mathrm{Aa}$ & $92.43 \mathrm{Cb}$ & & & & & \\
\hline 2 days at $19^{\circ} \mathrm{C}$ & $98.17 \mathrm{Aa}$ & $95.48 \mathrm{ABCa}$ & $91.98 \mathrm{BCb}$ & $88.42 \mathrm{BCC}$ & & & \\
\hline 4 days at $19^{\circ} \mathrm{C}$ & $97.71 \mathrm{Aa}$ & $95.11 \mathrm{ABCa}$ & $91.26 \mathrm{BCb}$ & $87.83 \mathrm{BCC}$ & $83.96 \mathrm{BCd}$ & & \\
\hline 6 days at $19^{\circ} \mathrm{C}$ & $97.23 \mathrm{Aa}$ & 93.94 BCb & $89.47 \mathrm{Cc}$ & $85.64 \mathrm{Cd}$ & & & \\
\hline 8 days at $19^{\circ} \mathrm{C}$ & $96.83 \mathrm{Aa}$ & $93.33 \mathrm{BCb}$ & $89.99 \mathrm{BCC}$ & $86.66 \mathrm{BCd}$ & $83.24 \mathrm{Ce}$ & & \\
\hline
\end{tabular}

in bract color of the inflorescences, as indicated by the $\mathrm{L}^{*}, \mathrm{a}^{*}$ and $b^{*}$ colorimetric variables (Table 4$)$. Flowering stems of Anthurium 'Ozaki Red' kept in distilled water $\left(22^{\circ} \mathrm{C}\right.$ and $\left.70 \%\right)$ were found not to exhibit a change in color until 12 days after harvest, when $a^{*}$ values decreased and $b^{*}$ values increased (Paull et al., 1985).

Table 4. Bract color (CIE L*, $a^{*}$ and $b^{*}$ ) of flowering stems of $\mathrm{H}$. bihai $\mathrm{Cv}$. Lobster Claw kept at $25^{\circ} \mathrm{C}$ under laboratory conditions (LC, control treatment) and after storage in cold chambers at 12 and $19^{\circ} \mathrm{C}$

\begin{tabular}{cccc}
\hline Treatment & L* & a* & b* $^{*}$ \\
LC (control) & $41.71 \mathrm{~A}$ & $59.88 \mathrm{~A}$ & $32.21 \mathrm{~A}$ \\
2 days at $12{ }^{\circ} \mathrm{C}$ & $42.18 \mathrm{~A}$ & $59.71 \mathrm{~A}$ & $31.63 \mathrm{~A}$ \\
4 days at $12{ }^{\circ} \mathrm{C}$ & $40.69 \mathrm{~A}$ & $61.61 \mathrm{~A}$ & $33.42 \mathrm{~A}$ \\
6 days at $12{ }^{\circ} \mathrm{C}$ & $42.57 \mathrm{~A}$ & $58.89 \mathrm{~A}$ & $32.20 \mathrm{~A}$ \\
8 days at $12{ }^{\circ} \mathrm{C}$ & $41.96 \mathrm{~A}$ & $58.79 \mathrm{~A}$ & $31.94 \mathrm{~A}$ \\
2 days at $19{ }^{\circ} \mathrm{C}$ & $42.73 \mathrm{~A}$ & $59.22 \mathrm{~A}$ & $33.19 \mathrm{~A}$ \\
4 days at $19{ }^{\circ} \mathrm{C}$ & $41.99 \mathrm{~A}$ & $59.62 \mathrm{~A}$ & $33.90 \mathrm{~A}$ \\
6 days at $19{ }^{\circ} \mathrm{C}$ & $42.31 \mathrm{~A}$ & $60.28 \mathrm{~A}$ & $33.03 \mathrm{~A}$ \\
8 days at $19{ }^{\circ} \mathrm{C}$ & $43.51 \mathrm{~A}$ & $58.22 \mathrm{~A}$ & $31.60 \mathrm{~A}$ \\
\hline
\end{tabular}

Note: Means followed by same capital letters in columns did not differ significantly $(p<0.05$; Tukey's test)

\section{CONCLUSIONS}

1. A temperature of $12{ }^{\circ} \mathrm{C}$ and relative humidity of $98 \%$ are indicated for the storage of flowering stems of $H$. bihai cv. Lobster Claw for up to four days, as periods longer than six days cause symptoms of chilling injury.

2. A temperature of $19^{\circ} \mathrm{C}$ and relative humidity of $99 \%$ are indicated for the storage of flowering stems for eight days, as these conditions increase total postharvest longevity.

3 . The storage of inflorescences at temperatures of 12 and $19^{\circ} \mathrm{C}$ did not alter bract color.

\section{ACKNOWLEDGMENTS}

The authors would like to thank the Brazilian fostering agencies Coordenação de Aperfeiçoamento de Pessoal de Nível Superior (CAPES), Conselho Nacional de Pesquisa (CNPq), and Fundação de Amparo a Ciência e Tecnologia de Pernambuco (FACEPE - PROMATA) for the financial support.
Thanks go to Atlantis Farm for donating the plant material and the Servio Nacional de Aprendizagem Industrial (SENAI) for lending the cold chambers. The authors are also very grateful to everybody from the UFRPE Laboratório de Floricultura for collaboration in all phases of the study.

\section{LITERATURE CITED}

Bellé, R. A.; Mainardi, J. C. C. T.; Mello, J. B.; Zachet, D. Abertura floral de Dendranthema grandiflora Tzvelev. 'Bronze Repin' após armazenamento a frio seguido de “pulsing”. Ciência Rural, v.34, p.63-70, 2004.

Berry, F.; Kress, W. J. Heliconia: An identification guide. Washington: Smithsonian Institution Press. 1991. 334p.

Bosma, T.; Dole, J. M. Postharvest handling of cut Campanula medium flowers. HortScience, v.37, p.954-958, 2002.

Castro, C. E. F.; May, A.; Gonçalves, C. Espécies de helicônia como flores de corte. Revista Brasileira de Horticultura Ornamental, v.12, p.87-96, 2006.

Chanasut, U. Treatments to maintain the postharvest quality of cut 'Patumma' (Curcuma alismatifolia 'Chiang Mai Pink') flowers. Acta Horticulturae, v.3, p. 1097-1101, 2005.

Finger, F. L.; Moraes, P. J.; Barbosa, J. G.; Grossi, J. A. S. Vase life of bird-of-paradise flowers influenced by pulsing and term of cold storage. Acta Horticulturae, v.2, p.863-867, 2003.

Geerdink, G. M.; Pinto, A. C. R.; Oliveira, R. F.; Minami, K.; Mello Dry, S. C. Storage of cut rolled leaves of Ctenanthe setosa on foliage postharvest longevity and quality. Acta Horticulturae, v.1, p.429-435, 2007.

Gorsel, R. V. Postharvest technology of imported and transshipped tropical floricultural commodities. HortScience, v.29, p.979-981, 1994.

Jaroenkit, T.; Paull, R. E. Reviews postharvest handling of heliconia, red ginger, and bird-of-paradise. HortTechonology, v.13, p.259-266, 2003.

Joyce, D. C.; Meara, S.A.; Hetherington, S. E.; Jones, P. Effects of cold storage on cut Grevillea 'Sylvia' inflorescences. Postharvest Biology Technology, v.18, p.49-56, 2000.

Kays, S. J. Postharvest physiology of perishable plant products. New York: Van Nostrand Reinhold, 1991. 532p. 
Mattiuz, C. F. M.; Rodrigues, T. J. D.; Pivetta, K. F. L.; Mattiuz, B. $\mathrm{H}$. Water relations of cut inflorescences of Alpinia purpurata treated with seven pulsing solutions. Acta Horticulturae, v.1, p.363-368, 2003.

Mayak, S. Senescence of cut flowers. HortScience, v.22, p.863865, 1987.

McGuire, R. G. Reporting of objective color measurements. HortScience, v.27, p.1254-1255, 1992.

Paull, R. E.; Chen, N. J.; Deputy, J. Physiological changes associated with senescence of cut Anthurium flowers. Journal American Society for Horticultural Science, v.110, p.156-162, 1985.

Reid, M. S. Effects of low temperatures on ornamental plants. Acta Horticulturae, v.1, p.215-223, 1991.
Reid, M. S. Advances in shipping and handling of ornamentals. Acta Horticulturae, v.1, p.277-284, 2001.

SAEG - Sistema para Análises Estatísticas e Genéticas. Versão 5.0. Viçosa: Fundação Arthur Bernardes, 1983.

Santos, M. H. L. C.; Santos, E. E. F.; Lima, GP.P. Soluções conservantes em sorvetão pós-colheita. Ciência Rural, v.38, p.2354-2357, 2008.

Silva, J. A. T. The cut flower: Postharvest considerations. Journal of Biological Sciences, v.3, p.406-442, 2003.

Skog, L. J. Chilling injury of horticultural crops. Horticultural Research Institute of Ontario. University of Guelph. Factsheet. http://www.omafra.gov.on.ca/english/crops/ facts/98-021.htm\#Figure\%203, 1998. 20 Jan. 2008.

Sonego, G.; Brackmann, A. Conservação pós-colheita de flores. Ciência Rural, v.25, p.473-479, 1995. 